UNIVERSIDADE DE BRASÍLIA

FACULDADE DE ECONOMIA, ADMINISTRAÇÃO, CONTABILIDADE E CIÊNCIA DA INFORMAÇÃO E DOCUMENTAÇ̃̃O (FACE)

ANTONIO GOMES DA SILVA FILHO

EFEITOS DA ORGANIZAÇÃO DO TRABALHO EM VIVENCIAS DE PRAZER E DE SOFRIMENTO DE TRABALHADORES EM ORGANIZAÇÃO PÚBLICA FEDERAL 


\section{EFEITOS DA ORGANIZAÇÃO DO TRABALHO EM VIVÊNCIAS DE PRAZER E DE SOFRIMENTO DE TRABALHADORES EM ORGANIZAÇÃO PÚBLICA FEDERAL}

Monografia apresentada ao Programa de PósGraduação em Administração (PPGA) da Faculdade de Economia, Administração, Contabilidade e Ciência da Informação e Documentação (FACE), da Universidade de Brasília, como requisito parcial à obtenção do grau de Especialista em Orçamento e Finanças.

Orientador: Prof. Dr. Marcus Vinícius Soares Siqueira

Brasília - DF 
A Elisa e Aline.

A meus pais (em memória). 


\section{AGRADECIMENTOS}

A Deus, minha grande fonte de inspiração!

A meus familiares, pelos exemplos de incentivo e firmamento.

A irmã Oneida, pela minha criação, pela fé, pelas orações.

A irmã Sônia, que sempre acreditou na minha capacidade.

A tio Geraldo, espirituoso, jovial, minha referência fashion.

A tio Francisco, excepcional exemplo de superação profissional.

A tio Sebastião, otimista, bem-humorado, auspicioso.

A minha "escadinha" de sobrinhos!

A Elisa e Aline, por me seguirem em similar caminhada.

A Janaína, Patrícia, Gilvan e Kátia, pelos muitos risos, ânimos e apoio.

Ao professor Dr. Marcus Vinícius Soares Siqueira, por me orientar nesse caminho.

A professora Dra. Maria de Fátima Bruno-Faria, pela simpatia e presença ricas.

Aos colegas do SERPRO-Sede, que me apoiaram nessa jornada. 


\section{Resumo}

O presente estudo tem como objetivo analisar os principais efeitos da organização do trabalho em vivências de prazer e de sofrimento de trabalhadores em uma organização pública federal. E como objetivos específicos, discutir e caracterizar conceitos de vivências de prazer e de sofrimento no trabalho; analisar o modelo de gestão gerencial, um modelo constituído de objetivos claros, bem definidos, e o modelo de gestão societal, embora ainda inacabado, com participação da sociedade, é voltado para as necessidades dos cidadãos; e, possibilitar a criação de estratégias de mediação para evitar o sofrimento e buscar o prazer, permitindo a identificação de fatores de risco para a saúde e para a qualidade de vida no trabalho. São enfocadas questões sobre como o processo de mudança institucional influencia a vida desses trabalhadores e como a manutenção da motivação pessoal são fundamentais na gestão de negócios dos processos organizacionais. Foi feita uma pesquisa por meio de entrevistas semiestruturadas com 10 (dez) funcionários desta organização sediada em Brasília - DF e identificou que as vivências de prazer e vivências de sofrimento estão primordialmente relacionadas com necessidade constante de aprimoramento de práticas na gestão de pessoas da organização, principalmente quanto a processos, planejamento e avaliação de desempenho, bem como na gestão de relacionamento com o cliente, seja ele interno ou externo à organização. Também é feita uma abordagem sobre como a modernização do setor público - com o modelo do gerencialismo - cria um ambiente competitivo, aumenta a possibilidade de adoecimento do indivíduo e precariza uma instituição pública. Alerta ou chama a atenção, que reflexões são necessárias e devem ser observadas pelos seus dirigentes sobre a situação geral dos servidores públicos por vezes criticados pela sociedade, vistos ou rotulados de ineficientes até mesmo pelo próprio ministério ou área a que estão vinculados. Finalmente, sinaliza que o trabalhador motivado, reconhecido, tende a oferecer um atendimento de qualidade de serviços prestados ao cidadão, ao seu cliente, ao cidadão-cliente; e ele, o trabalhador, em geral está sempre pronto para dar o seu melhor de si nas mais diversas áreas organizacionais da instituição: Planejamento, Orçamento e Finanças, Gestão de Pessoas.

Palavras-chave: vivências; prazer; sofrimento; trabalho; subjetividade. 


\section{SUMÁRIO}

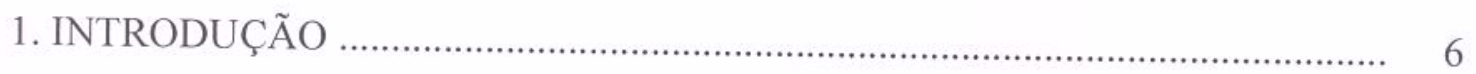

2. FUNDAMENTAÇÃO TEÓRICA.................................................................... 8

2.1. Contextualização sócio-organizacional................................................ 8

2.2. A administração pública e suas reformas por uma nova gestão pública... 9

2.3. Vivências de prazer e de sofrimento no ambiente de trabalho................. 12

3.METODOLOGIA.

3.1. Instrumento da coleta dos dados......................................................... 22

3.2. Procedimentos da coleta de dados............................................................. 22

4. ANÁLISE E DISCUSSÃO DOS RESULTADOS................................................. 24

4.1. Contexto de trabalho: o dia-a-dia do trabalhador...................................... 24

4.2. Exigências decorrentes do contexto de trabalho........................................ 28

4.3. Problemas (físicos, psicológicos e sociais) nos últimos 6 meses causados, essencialmente, pelo trabalho........................................................ 30

4.4. Percepções nos últimos 6 meses sobre os efeitos em vivências de prazer

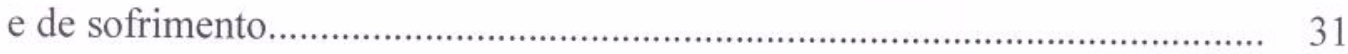

5. QUADRO RESUMO DOS EFEITOS EM VIVÊNCIAS...................................... 34

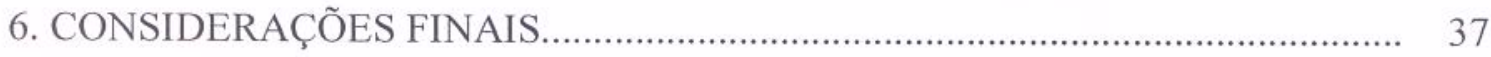

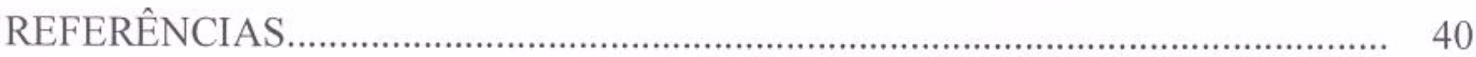




\section{Introdução}

Nas últimas décadas, as principais teorias sobre o comportamento organizacional e o processo de mudança institucional vêm sendo objetos de estudo e de análise no setor público brasileiro. Comumente, vivenciamos a existência do sofrimento nas organizações como pressões, ameaças, exclusões a realizações, ao crescimento no trabalho; e, assim, o prazer no trabalho e o bem-estar social ficam comprometidos. As condições de vida, nosso árduo cotidiano, às vezes exasperam ou estressam o trabalhador, têm exigido, cada vez mais, dedicação e responsabilidades. Esse sofrimento, físico e/ou mental, que assola o trabalhador, numa escala sem precedentes e num mundo globalizado, interfere de forma abrupta e profunda nas relações entre organizações e indivíduos e impacta o ambiente social. Paralelamente a isso, verificamos que as organizações têm assumido papel de relevância na sociedade e na vida das pessoas com o trabalho como fonte de sobrevivência, de prazer e saúde; e, a empresa, essa sim, marcada pela prevalência do econômico influenciando o consumo e a produção e identificando as pessoas, certifica-se, o sucesso é medido pela progressão na carreira e pela posição social adquiridos no decorrer do tempo.

Muitas vezes, percebe-se a existência de vultosos discursos recheados de motivações ao sucesso, à carreira. Entretanto, na prática, vê-se que o poder e o domínio são vorazes, falam mais alto transgredindo valores morais e éticos a favor da exploração desse mundo moderno do trabalho, trazendo sentimentos de insegurança, medo, incerteza, dentre outros sofrimentos. Produtividade, eficiência e eficácia, metas inatingíveis, são o que o modelo prega a todo tempo. O capital humano submetido à organização, às vezes desvalorizado, acaba sendo instrumento de exploração e subserviência do poder. Enquanto isso, por razões restritivas, o sofrimento do trabalhador, pouco compreendido e valorizado, vem trazendo efeitos nocivos à sociedade e por motivos físico e psíquico o leva ao adoecimento. Os processos de avaliação de desempenho, cada vez mais aprimorados e soberbos à eficácia, desfilam-se mutilando os sonhos ou diminuindo as esperanças do trabalhador atribuindo-o ineficiência ou incapacidade na administração pública para a geração de resultados. $\mathrm{O}$ indivíduo se torna escravo do trabalho, pois é nivelado ou avaliado por baixo, muito aquém do esperado, e esse transtorno pelo não reconhecimento da prática nas suas atividades, coloca-o em posição desfavorável à organização quanto aos princípios éticos e morais, pois o seu empenho pouco ou nada foi ou será reconhecido. 
Pretende-se com este estudo, como objetivo geral, analisar os efeitos da organização do trabalho em vivências de prazer e de sofrimento de trabalhadores em uma organização pública federal e como objetivos específicos:

- Discutir e caracterizar conceitos de vivências de prazer e de sofrimento no trabalho;

- Analisar o modelo de gestão gerencial, um modelo constituído de objetivos claros, bem definidos, e o modelo de gestão societal, embora ainda inacabado, com participação da sociedade, é voltado para as necessidades dos cidadãos;

- Possibilitar a criação de estratégias de mediação para evitar o sofrimento e buscar o prazer, permitindo a identificação de fatores de risco para a saúde e para a qualidade de vida no trabalho, como:

- O processo de mudança institucional influencia a vida desses trabalhadores?

- A manutenção da motivação pessoal é fundamental na gestão de negócios dos processos organizacionais?

Este trabalho poderá ajudar a identificar, ampliar, discutir e analisar conjunturas ou contextos na execução de programas, projetos e atividades de interesse de gestão de pessoas, gestão de negócios, esclarecendo situações ou circunstâncias que possam minimizar ou tornar suportável a vivência de sofrimento, criando um sentido para o trabalho e para a vivência de prazer pela transformação da organização do trabalho, enfim propõe ser objeto de ampliação de futuros estudos sobre essas vivências.

Compreende, portanto, esta parte introdutória; depois, faz uma contextualização sócio-organizacional passando pela explanação do modelo gerencial de administração pública introduzido pela reforma de Bresser Pereira por uma nova gestão pública; em seguida, trata o cenário que afeta ou se encontram os trabalhadores em uma organização pública federal sob os efeitos da organização do trabalho em vivências de prazer e de sofrimento, abrangendo tópicos conceituais sobre a identidade no trabalho e circunstância de trabalho precarizado. Na terceira parte está a metodologia, onde são investigados os efeitos propriamente ditos da organização do trabalho em vivências de prazer e de sofrimento, momento esse em que, num capítulo seguinte, são analisados e discutidos os resultados e tecidas as considerações finais. 


\section{Fundamentação teórica}

Os temas relacionados ao campo do trabalho na administração pública, das relações de prazer e de sofrimento no trabalho em análise, como psicodinâmica do trabalho, gestão como doença social, reforma do estado e administração pública gerencial, por uma nova gestão pública, a banalização da injustiça social, gestão de pessoas e discurso organizacional, são considerados essenciais para fundamentar esta pesquisa.

\subsection{Contextualização sócio-organizacional}

Não se pode falar em planejamento empresarial, orçamento, finanças, dinâmica organizacional sem antes pensar na organização do trabalho, no estado de espírito ou bem-estar do indivíduo, analisar suas vivências de prazer, vivências de sofrimento e suas expectativas de realizações. O indivíduo tem de estar bem consigo mesmo para desempenhar suas atividades, suas responsabilidades, enfim tudo caminha em função de respostas advindas de seus aspectos físico, psicológico e social.

Quando vemos uma organização em pleno vapor de funcionamento, deve-se suscitar preocupações com várias temáticas, como contexto de trabalho e suas exigências decorrentes. E, logo requer entendimentos com planejamento estratégico, missão, valores, crenças, normas e traz a ideia de resultados, desempenho, competitividade, liberdade, cooperação, reconhecimento, recompensa, justiça, satisfação, motivação.

Em gestão de negócios, gestão de pessoas ou contextos à luz de execução de programas, projetos, atividades de atendimento de demandas ou atendimento ao cliente, são situações que comumente se depara uma organização pública federal no seu dia-adia. Exigências da lei, tempestividade, pressões no cotidiano existem a todo instante para esse trabalhador e podem levá-lo ao adoecimento.

Assim, esta pesquisa procura esclarecer circunstâncias que possam ser objeto de estudo visando minimizar ou tornar suportável a vivência de sofrimento, criando um sentido para o trabalho e para a vivência de prazer pela transformação da organização do trabalho. Permite a oportunidade de situar no desempenho de sua função o profissional, o especialista, o gerente, a alta direção numa nova visão para atentar detalhes de gestão e de governabilidade, que às vezes passam despercebidos prejudicando a organização como um todo, porque o setor público, como é visto 
adiante, é bem diferente do setor privado. A partir do modelo burocrático, são conjuntamente aqui estudados a nova gestão pública: os efeitos que o modelo gerencial pode acarretar ao modelo societal. Identifica-se que tanto o modelo burocrático, quanto o gerencial podem ter boa convivência entre si, mas certamente com adaptações.

O estudo da saúde e das patologias do trabalho, visto em Mendes e Gaulejac (2007), retrata o sofrimento do trabalhador público. O ativismo desenfreado desses trabalhadores vivendo a doença social do medo de perder as gratificações, da pressão do sempre mais, da ameaça de perder o lugar, de não mais estar à altura das expectativas da organização, são assuntos ainda pouco explorados ou debatidos, que devem suscitar preocupações à administração pública. Por um lado, esse trabalhador tem que seguir normas, leis, regulamentos; e por outro, tem que atingir metas com eficiência. Enfim, frequentemente, ele sofre as amarras tanto do modelo burocrático quanto do modelo gerencial. A busca de melhoria da relação indivíduo-empresa e o nosso próprio posicionamento perante o discurso organizacional, Siqueira (2006) reavalia o sentido do trabalho em nossas vidas e nos possibilita compreender melhor o lado oculto desse discurso em gestão de pessoas.

\subsection{A administração pública e suas reformas por uma nova gestão pública}

A administração pública brasileira vem passando por mudanças desde a década de 1930 com o objetivo de tornar-se mais ágil e eficiente. A reforma do estado e a melhoria das formas de gestão pública tornaram tema fundamental a partir dos anos 1990, uma vez que a crise do Estado e o processo de globalização em curso mostraram que não bastava reduzir ao mínimo o Estado, era preciso reconstruí-lo. A primeira reforma ocorre em 1933 com a criação do Departamento de Administração do Serviço Público (DASP) em busca de um estado moderno e de uma burocracia pública profissional. A segunda veio durante o regime militar, trouxe em seu meandro a chamada tecnocracia estatal, que exclui a sociedade das decisões governamentais. Depois, a partir de 1995, com a reforma administrativa produzida pelo Ministério da Administração Federal e Reforma do Estado Brasileiro (MARE) veio a chamada administração pública gerencial, já praticada em vários países nos anos da década 1980 , que preconizava tratar o provimento serviços públicos como um negócio e fazer migrar para a administração pública o modo empresarial de se trabalhar, contrapondo às práticas burocráticas do governo. É nesse período que vieram os conceitos de qualidade 
total pelos princípios da Gestão da Qualidade Total (GQT), a reengenharia, o downsizing, o benchmarking e a administração participativa ao setor público (DE PAULA, 2005). Cabe ressaltar, estão em análise neste trabalho apenas os pontos que puderam agravar o sofrimento dos servidores públicos, mas vale lembrar dos objetivos dessa administração pública gerencial que, segundo esta autora, são:

\footnotetext{
"Melhorar as decisões estratégicas do governo e da burocracia; garantir a propriedade e o contrato promovendo um bom funcionamento dos mercados; garantir a autonomia e capacitação gerencial do administrador público; assegurar a democracia através da prestação de serviços públicos orientados para o "cidadão-cliente" e controlados pela sociedade."
}

E para alcançar esses objetivos para os três níveis governamentais (federal, estadual e municipal), prossegue a autora, esse novo modelo de gestão deve ter uma administração profissional, autônoma e organizada em carreiras, ser descentralizada administrativamente, ter maior competição entre as unidades administrativas, maior controle dos resultados, ter disciplina e parcimônia no uso dos recursos, possuir indicadores de desempenho transparentes e ter ênfase no uso de práticas de gestão originadas no setor privado.

Na Reforma do Estado e Administração Pública Gerencial de Bresser-Pereira e Spink (1998), a administração pública nesse modelo deve ser constituída por servidores públicos da maior competência, bem remunerados e que estejam imbuídos pela ética do serviço público: o dever de servir ao cidadão.

A ideia de constar nesse modelo a qualidade total, compreende a valorização da participação e da iniciativa do servidor nos princípios da satisfação do cliente, constância de propósitos, melhoria contínua (Ciclo PDCA - Pĺanning-doing-checkingacting), gestão participativa e valorização dos servidores (DE PAULA, 2005). Com isso, vieram questões como reformulação e/ou enxugamento da máquina com a extinção de funções, redução de gastos, cortes de pessoal e mudanças no regime de contratação.

Para satisfazer essas novas exigências impostas por esse modelo, o funcionalismo passa a adotar comportamentos frequentemente contraditórios aos habituais, sente-se oprimido, pressionado, apreensivo e ansioso no seu dia-a-dia. O então Ministro Bresser-Pereira, reconhece que à época o servidor público viu-se com sua imagem negativa, pois ela já não era mais embasada no chamado modelo 
burocrático e sim no gerencial, que estabelecia a flexibilização do estatuto da estabilidade (DE PAULA, 2005). Além de não substituir o modelo anterior, complementa a autora, os controles dos processos passam dos políticos para os tecnocratas, o modelo é questionável, ainda não acontece com a participação popular, afeta a auto-estima e causa sofrimento com estresse, tensões e angústias.

Os desafios para a construção de uma nova gestão pública nos remete a analisar um contexto sociopolítico mais abrangente de um Estado com suas características e fundamentos nas demandas populares com uma efetiva participação da sociedade, vertente esta marcada pelo modelo gerencial e com a participação das propostas do modelo de gestão societal, embasado pela construção de instituições políticas e políticas públicas mais abertas à participação social e voltadas para as necessidades dos cidadãos.

Ao modelo gerencial, a ênfase recai sobre dimensões econômico-financeira e institucional-administrativa; ao societal, volta-se à visão sociopolítica, uma vez que este não tem propostas completamente acabadas, ao passo que a vertente gerencial possui um plano claro com objetivos definidos, o que contribui para o aparelho do Estado para a permanência da proposta gerencial. É preciso acrescentar que a continuidade do modelo gerencial impossibilita mudanças na cultura política, pois condiciona a forma como a gestão do aparelho do Estado é realizada. Existe uma crença na eficiência da participação da sociedade na formulação das políticas públicas, após serem atribuídas pelos burocratas das secretarias de governo para serem controladas ou executadas pelas Agências Executivas ou pelas Organizações Sociais. Esta participação social, sabe-se, não existe na prática, pois não há a transparência necessária ou esperada e nem mecanismos para que isso ocorra, pois não existe um canal de mediação entre as entidades e a cúpula governamental, evidenciando que está colocado o desafio de se elaborar arranjos institucionais para viabilizar uma maior participação dos cidadãos na gestão pública. No âmbito societal existem os fóruns temáticos, os conselhos gestores de políticas públicas e o orçamento participativo. Mas, ao mesmo tempo, também verifica-se que estas manifestações têm limites, pois são locais, fragmentárias e desarticuladas de um projeto global para reforma do Estado. No gerencialismo, existe a imitação do setor privado, e com isso adia a elaboração de ideias, modelos e práticas administrativas que atendam às especificidades do setor público e a demanda por participação popular. Em suma, a administração pública tem uma lógica própria de funcionamento, requerendo, para isso, o desenvolvimento de técnicas de gestão 
adequadas, além de uma formação específica para os gestores públicos, como também tende ao rompimento com os modelos administrativos e fórmulas prontas, porque estes não são capazes de refletir ou de atender a complexidade dos processos políticos e sociais (DE PAULA, 2005).

\subsection{Vivências de prazer e de sofrimento no ambiente de trabalho}

Criar uma identidade no trabalho é um desejo, uma fonte de prazer do trabalhador, mesmo em circunstância de trabalho precarizado. Ser solidário, ser colaborador, é uma das formas de vivenciar na organização do trabalho a minimização de situações de estresse, de sofrimento. O estudo do trabalho e da saúde e suas interrelações com a subjetivação e o processo saúde-adoecimento, as estratégias de mediação, são formas que buscam equalizar prazer-sofrimento na organização do trabalho. "Subjetivação é o processo de atribuição de sentido, construído com base na relação do trabalhador com sua realidade de trabalho, expresso em modos de pensar, sentir e agir individuais ou coletivos.” (MENDES, 2007, p. 30).

Mudanças no mundo do trabalho nos anos 1990 com a reestruturação produtiva, a acumulação de capital e o mundo ainda mais globalizado com empresas transoceânicas, trazem novas formas de organização do trabalho e novas formas de subjetivação e de sofrimento, e fazem surgir, consequentemente, novas ações e reações dos trabalhadores. Inteligência prática e o espírito de colaboração possibilitam a sociabilização e transformação do trabalho. O indivíduo domina o seu trabalho, favorece novas formas no desenvolvimento de suas tarefas, quebra paradigmas, regras ou normas e ainda assim atende aos objetivos da produção, sendo eficaz mesmo executando de outra forma como prescreve a organização do trabalho. A ação de colaboração para produzir uma ideia, um serviço ou um produto pode ser relevante e fazer sentido, e também, da mesma forma, produzir talentos específicos, dar valorização e reconhecimento ao indivíduo que participa do coletivo. Paralelamente, se o ganha-pão é o sentido do trabalho, pode-se instalar a precarização dos contratos de trabalho, caracterizada por elementos que geram sofrimento em virtude das demandas serem atendidas pelo indivíduo em volume cada vez maior e além da sua capacidade normal, inevitavelmente estendendo a sua jornada de trabalho. Esse indivíduo colaborador é um candidato a tornar-se servidor voluntário, ou seja, ele vai se dedicando cada dia mais a

novos experimentos ou cooperações que, quando se dá por conta, já está mergulhado ou 
comprometido em extensas horas adicionais de trabalho no seu dia-a-dia, está conformado e integrado em atender a seus gestores, submisso e sem protestos e, nesse ínterim, instala-se a banalização do sofrimento sempre com formas mais violentas e cruéis contra si mesmo, e a vida familiar e social perdem o sentido, são imperiosamente degradadas.

A clínica do trabalho trata a abordagem sócio-psíquica do trabalho e não o individuo, onde é fundamental a escuta e interpretação da fala, e parte do pressuposto de que a fala deve ser interpretada em espaço público. Assim, o indivíduo em suas relações no contexto de trabalho pensa e relata suas experiências para o pesquisador e revela suas relações que o sustentam e as possíveis adversidades da organização do trabalho possibilitando esclarecer as vivências de prazer-sofrimento e a saúde no trabalho. A clínica do trabalho pode construir o conhecimento para interpretar e analisar questões que levam ao sofrimento nas organizações do trabalho, uma vez que qualquer trabalho pode transformar-se em uma patologia e a psicodinâmica aproveitar-se disso, a partir desse conhecimento, e ser instrumento capaz de interpretar o estudo da saúde e das patologias do trabalho (MENDES, 2007).

Indicar que as mudanças devam se processar especificamente na direção de aumentar a realização profissional e diminuir a falta de reconhecimento e esgotamento profissional na relação saúde e trabalho, a importância das práticas de gestão que devem favorecer a construção e desenvolvimento de gestão principalmente em políticas de saúde e qualidade de vida no trabalho, são estratégias para minimizar o sofrimento e o adoecimento.

Minimizar o sofrimento e aumentar as vivências de prazer no ambiente de trabalho inquestionavelmente é da maior relevância. No universo gerencialista da gestão como doença social, o medo de perder as gratificações, de não mais estar à altura das expectativas da organização, é tão assim quanto uma criança que tem medo de perder o amor de sua mãe. Diante dessa tremenda angústia, o modo privilegiado de defesa é o recuo sobre si mesmo e o ativismo desenfreado. O trabalho se torna uma obsessão, os sujeitos se concentram sobre seus objetivos e toda distração é sentida como perturbação insuportável e contra o desempenho do indivíduo. A tensão cria condições propícias para o assédio, seja numa posição perversa, na qual os outros são percebidos como objetos utilitários; seja numa posição masoquista de vítima, na qual o outro é fonte de um sofrimento pelo qual não se quer passar; ou numa posição paranoica, na qual o 
outro é percebido como um perseguidor. A vivência dessas diferentes posições está ligada a componentes psíquicos já presentes. Uns têm uma propensão a se posicionar como executores dóceis da vontade de outrem, outros como vítimas ou ainda como carrascos. Definitivamente, são as condições de trabalho que solicitam e favorecem tal ou tal funcionamento psíquico (GAULEJAC, 2007).

Pressões no trabalho com ameaças do emprego cada vez maiores, precarização dos métodos de gestão para almejar mais produtividade, disponibilidade e renúncia, fazem parte, são usados e são verdadeiras armadilhas que levam à banalização da injustiça social, trazendo como consequência o sofrimento, o adoecimento dos trabalhadores, dificultando ou não se estabelecendo o equilíbrio na relação de prazersofrimento (DEJOURS, 2007).

A crise que se apresenta aos trabalhadores, ressalta este último autor, tem seu início na natureza do sistema econômico, no mercado ou na globalização. Todavia ele explica, que as condutas humanas diante dessas situações têm contribuído e muito para agravar os problemas no dia-a-dia no trabalho, principalmente no que diz respeito ao sofrimento. Os indivíduos somente sobreviverão no mercado do trabalho se superarem a si mesmos, sendo cada vez mais competitivos ou mais eficientes entre si, à equipe ou aos concorrentes, com atitudes voltadas para a individualidade. Também, que as motivações subjetivas do consentimento são determinantes ou têm um papel importante sobre o sofrimento no trabalho que aumenta, é crescente, à medida que os trabalhadores vão perdendo gradualmente a esperança de que a condição que hoje lhes é dada possa amanhã melhorar e, cada vez mais, vão se convencendo de que sua dedicação, seus esforços e boa vontade pela empresa só acabam por agravar a situação.

Complementa o autor, as consequências que assolam não só a saúde física, mas também a psíquica, trazem a esses indivíduos mecanismos de estratégia de defesa para aliviar, suportar ou superar esse sofrimento. Nesse caso, a estratégia, que pode ser individual ou coletiva, torna com que muitas coisas inaceitáveis sejam aceitáveis. É de fato uma cilada, pois percebe-se a banalidade ou descaso da percepção daquilo que faz o indivíduo sofrer, instala-se no indivíduo a opinião do deixa pra lá, não faz diferença fazer ou deixar de fazer. A ressignificação das atividades de trabalho de modo a minorar os conflitos, a insatisfação, o desprazer, deve ser equilibrada, renegociando e induzindo os danos aos menores possíveis. Trabalhar não deve ser tão-somente cumprir uma tarefa, mas também viver a experiência de enfrentar resistência, crítica, e, realmente, ter 
a possibilidade de experimentar o sentimento de prazer ou sofrimento.

Entraves, novos cenários, mudanças institucionais, fatores motivacionais, levam a novas situações de organização do trabalho e fazem surgir novas ações e reações dos trabalhadores, com a inteligência prática e o espírito colaborativo. $\mathrm{O}$ indivíduo quebra regras, transcende normas, utiliza-se da criatividade para atender aos objetivos da produção: eficiência versus eficácia. Ele deseja a perenidade do seu trabalho; mas, muitas vezes, isso tem um preço e o expõe a fatores de risco, como vemos em Siqueira (2006):

- A servidão voluntária do indivíduo - atitude servil, humilhação - existe porque está presente nele a fascinação e a relação de submissão dele nas organizações. Institucionalizada, a servidão se vê impregnada de ideais da organização, como normas, valores, convicções e padrões de conduta, e visando à sua continuidade, o indivíduo, envolvendo-se cada vez mais com esses ideais, servindo a ela e a seus dirigentes, é manipulado pela organização antes que aconteça conflitos, uma vez que a organização tem essa prerrogativa de visualizar antecipadamente essas questões e tomar medidas cabíveis entrevendo que o indivíduo continua submisso aos seus caprichos, aos seus desejos;

- A fascinação e a sedução. Impor a sua cultura e dominar o inconsciente do indivíduo são ações exercidas pelas organizações com a fascinação e a sedução. O indivíduo se torna mais apegado à organização emocionalmente, com isso, ela tem nele um aliado para qualquer situação. Na fascinação, o indivíduo está impressionado, encantado, tão submisso com a organização, pode até querer ter liberdade de pensar e de agir, mas em cima da missão e dos valores por ela definidos o seu desejo em servi-la fala mais alto, não o deixa agir e ele continua como está. Na sedução, a ele é imputado o papel ou fantasia de ser algo ou alguém diferente dos outros, como de que ele poderá se tornar um herói, um semideus, ser feliz na empresa seguindo as vertentes traçadas pelos processos de melhorias contínuas. Ele se vê comprometido, seduzido a se identificar cada vez mais com a organização, tornando-se seu prisioneiro e aderindo totalmente seu tempo e seu pensamento aos projetos da organização em troca de dinheiro e de reconhecimento.

Em relação a questões sobre como o processo de mudança institucional influencia a vida desses trabalhadores, percebemos que essa mudança passa pela modernização da tecnologia da informação, responsável pela reestruturação do sistema 
capitalista (CASTELLS, 2001) reorientando as relações de trabalho nas organizações com a multifuncionalidade do empregado, que deve estar preparado para exercer diferentes funções na sua organização (ANTUNES, 2002). A mudança institucional, prossegue este autor, está intimamente ligada com o processo de privatização, de desregulamentação da economia com o intuito de desenvolver o capital, as forças produtivas, com os direitos dos trabalhadores sendo modificados pelas leis trabalhistas. Assim, a união que antes existia da força de trabalho torna-se frágil, impotente, precarizada e os sindicatos das categorias já não são mais como antes. Neste cenário, as empresas passam a existir ou a coexistir em função da justificativa para o enfrentamento de crises, elas demitem em massa quando bem entendem, prolongam as jornadas de trabalho e suas estruturas e o processo produtivo são constantemente modificados visando atingir altas taxas de produtividade para maximizarem seus lucros ou minimizarem suas perdas.

Começam a existir, cada vez mais, os serviços sociais especialmente ligados à saúde do trabalhador. Surgem novas formas de gestão da produção baseadas em forçatarefa para ter respostas imediatas a situações-problema. Novas técnicas e ferramentas de gestão são consolidadas, integradas e adotadas como modelo. O indivíduo torna-se um colaborador com os colegas do seu grupo de trabalho, visando sempre o aumento da produtividade para suplantar os desafios comumente surgidos, atingir os resultados esperados, e se torna, com os treinamentos aplicados, cada vez mais um especialista multifuncional. As empresas buscam a utilizar ao máximo os recursos humanos, com suas políticas demasiadamente valorizadas, e de forma crescente, uma vez que os indivíduos são considerados seu principal ativo. Nessa mudança institucional, as empresas, cada vez com mais relevância na sociedade moderna, vão substituindo as funções e o poder do Estado, e vão mudando, sempre que necessário, as políticas de gestão de pessoas, é de acordo com a sua situação econômica em que se encontram. Assim, se a empresa possui uma mão-de-obra treinada, especializada, ela está pronta para obter dos seus membros a inovação em seus produtos e serviços, uma vez que esses membros só estarão participando do seu quadro porque eles estarão satisfazendo suas principais políticas de gestão de pessoas: são indivíduos cooperativos e sabem trabalhar em equipe. E mais do que isso, sabem se relacionar não apenas entre si, mas também com a empresa e com o desenvolvimento tecnológico envolvido no processo produtivo. É claro, isso não leva ao aumento do benefício do trabalho, mas sim a 
intensificá-lo cada vez mais (SIQUEIRA, 2006). A flexibilização organizacional é uma medida adotada pelas empresas quando se deparam com o aumento da competitividade, exigindo mudanças em termos de sua produção, para que venham responder às novas demandas do mercado (HELOANI, 2003). Assim, as empresas mudam suas estruturas organizacionais continuamente criando, alterando, excluindo, e também mudam de localizações. Enfim, mudam seus modelos organizacionais, à medida que necessitam atender às transformações do mercado, com inovações de seus produtos ou serviços, para atender as necessidades dos seus clientes. Essa flexibilização de seus modelos é fundamental para elas, porque contribui para que burocracias verticais se tornem cada vez mais horizontalizadas. Logo, surge a terceirização com a subcontratação, onde o trabalho, reduzido para diminuir custos de produção, começa a ficar ainda mais fragmentado, e com a descentralização produtiva, vemos os sindicatos e os trabalhadores perderem força, levando a desemprego, à desregulamentação do trabalho (SIQUEIRA, 2006), que começa a ser definido por contrato por período determinado, temporário ou estipulado por projeto específico, a exemplo temos as fábricas de software, aonde o indivíduo vai apenas interessar para a organização no período de vigência do contrato e depois disso é dispensado, sem que exista qualquer vínculo empregatício. Para isso, existe um grupo permanente e intimamente ligado à empresa que administra seus projetos, contratos, organizando os trabalhos para que ocorram sempre dentro dos planos ou cronogramas estabelecidos. O Ministério do Trabalho e Emprego (MTE) tem se pronunciado contra essa prática, muito comum hoje em dia, e dado ganho de causa ao trabalhador mandando registrá-lo retroativamente e garantindolhe todos os direitos regidos pela Consolidação das Leis do Trabalho (CLT).

A motivação pessoal é fundamental na gestão de negócios dos processos organizacionais. Ela está facilitada pela mudança da coerção para a gestão do afetivo. E o amor-fusão, do indivíduo seduzido e fascinado pela organização, é definido como uma das formas de controle cada vez mais usuais nas organizações modernas. Por meio deste amor, a empresa domina o íntimo do indivíduo, levando-o a entregar sua alma para a organização e para a cultura desta (ENRIQUEZ, 1991). Com esse tipo de controle em todas as dimensões do indivíduo, atuando com sua estrutura mais flexível (mais horizontalizada que verticalizada) e baseada em equipes de trabalho, as organizações terão sucesso, sendo fundamental que o indivíduo adote esse discurso organizacional e esteja pronto para atender aos desejos da organização. E, de fato, virá o 
sucesso, uma vez que o indivíduo está condicionado a alcançar os resultados esperados, pois a empresa o trata como um herói, o salvador-da-pátria e a ser o capital bem investido por ela.

As organizações vão invadindo a vida privada do indivíduo, sua vida extra-profissional e a família, por vezes, é colocada a sacrifícios por causa de bônus, prêmios sutis e reconhecimentos financeiros por elas oferecidos. O estresse, a carga extra de trabalho, é dito, será compensado por alguns dias ou um fim de semana de descanso, o que é uma inverdade e improcedente. Este controle é para manter a organização estável e uniforme. A motivação está calcada na remuneração porque dessa surgem o comprometimento e a parceria com a organização para que busque o cumprimento de seus objetivos e planos, principalmente o retorno financeiro, que é o lucro; e para o indivíduo talvez haja esse pseudo-ganho ou ao menos promessas de sucesso e de realização (SIQUEIRA, 2006). Políticas de gestão de pessoas tendem a reter os talentos da organização e fazer uso de seus conhecimentos e habilidades com vistas ao aumento da competitividade no mercado. Ao indivíduo cabe buscar o sucesso, porque não existe na organização lugar para fracassados ou pessoas pouco ambiciosas, pois as empresas exigem renúncia e sacrifício, e em troca prometem a glória e o triunfo. O indivíduo precisa trabalhar muito! Entregar-se totalmente à organização, ser um super-herói, para ser o melhor e alcançar o reconhecimento e a admiração desejados por ele. A organização tem no seu líder um sedutor que se utiliza de todos os artifícios, desde prêmios a "pequenos-gestos" de amor: ele oferece rosas e bombons, e ela faz uso cada vez mais frequente de programas de integração entre seus funcionários e familiares, trazendo a família destes para dentro dela, de forma a tornar as relações familiares cada vez mais influenciadas pelo mundo dos negócios (SIQUEIRA, 2006).

As organizações, visando dominar o motivacional do trabalhador, coercitivamente tentam fazer com que o indivíduo, mesmo após a uma boa avaliação de desempenho, seja eternamente devedor a ela dizendo que o índice ou a escala da nota ainda é baixa é para ser um incentivo à melhoria até a próxima avaliação e assim ele achar que não está na hora de pedir melhorias ou aumento nos seus benefícios ou rendimentos. A motivação também decorre pela participação na distribuição de lucros pelas organizações e de prêmios por metas alcançadas, o que faz com que o indivíduo se dedique com mais afinco aos objetivos institucionais. Desta forma, estará mais motivado em cumprir suas tarefas cotidianas e alcançar suas metas, e sua participação é 
mostrada como uma benesse da organização, que nesse caso não teria nenhuma obrigação para praticar tal atitude. A união faz a força é o discurso organizacional para melhorar o clima organizacional. Ele é utilizado para aumentar a comunicação, fazendo com que o sindicato tenha seu peso político diminuído, uma vez que prega que o melhor aliado de uma organização contra os seus concorrentes é seu próprio empregado, que estará no mesmo barco com os demais em prol do mesmo objetivo: a perenidade da organização. $\mathrm{O}$ intuito é a identificação de líderes para se evitar greves, mostrando que o empregado é ouvido (SIQUEIRA, 2006).

A saúde do trabalhador. As organizações se mostram preocupadas com a saúde do indivíduo pagando plano de saúde para ele ou adquirindo equipamentos de segurança, mas o que não é sempre dito é que a grande preocupação delas é com a produtividade de seus empregados. Se necessário até enviar algum deles para a clínica de repouso, por exemplo, elas o farão; basta que ele seja, de fato, importante para o seu processo produtivo. Casos de discurso sobre qualidade de vida no trabalho, no fim das contas, elas vão preferir ignorar assédio moral ou outros danos causados aos indivíduos no âmbito das relações de trabalho. E os desequilíbrios entre prazer e sofrimento vivenciados nesse cotidiano nas organizações tornar-se-ão necessário ao indivíduo encontrar meios para superá-los em suas adversidades, resolvendo-os. As organizações auxiliam nas dependências químicas, mas não é dito que muitos desses problemas são causados pela pressão no trabalho, pelas constantes preocupações do indivíduo em ser demitido, pelo incentivo à competitividade sem limites e pelo estímulo para ele ser um vencedor. E quando falam de acidentes de trabalho, elas pensam nos gastos com segurança que terão e o retorno que não terão em curtíssimo prazo. O ponto que não se nota é a preocupação com a vida humana, mas sim com a produtividade, com retornos ou seus objetivos organizacionais. Existe o fato de que elas têm bem registrada ou acompanhada a série de problemas de saúde de seus empregados, uma vez que estes têm medo de demonstrar fraqueza ou admitir que possuem alguma doença, como a depressão, vista negativamente por elas. $\mathrm{O}$ discurso vigente é que as empresas deveriam cuidar de seus empregados e eles deveriam sempre confiar nas empresas, isso é o mínimo que eles poderiam dar de retorno a essa atitude da organização.

Por fim, para melhorar sua imagem e reter talentos, a organização paga salários elevados e dá vários benefícios. O indivíduo é sujeito à capacitação contínua, é obrigado a estar sempre atualizado e, com isso, pode ser levado à angústia e ao sofrimento, pois 
não é possível estar sempre na crista da onda, ou seja, estar sempre com seus conhecimentos atualizados. Na melhor empresa para se trabalhar, o indivíduo se sente orgulho em pertencer à organização. Lá, a gestão do afetivo está presente o tempo todo nas relações de trabalho, o indivíduo é seduzido e se deixa seduzir para fazer parte dessa grande família-empresa. Ser vitorioso e alcançar o sucesso são promessas vigentes; e o indivíduo, seguindo a receita da empresa, sendo criativo e continuamente inovador, vai alcançar esta vitória e será recompensado. O que ele não espera é que após vinte anos de empresa, por exemplo, possa estar na derradeira lista negra para ser demitido, e que o jogo acabou. É triste, mas é realidade sua morte naquela empresa, e isso pode ser até mais que uma metáfora! (SIQUEIRA, 2006). 


\section{Metodologia}

Neste trabalho, foi aplicada aos entrevistados uma pesquisa qualitativa para averiguar suas percepções sobre os efeitos da organização do trabalho em vivências de prazer e de sofrimento, sem nenhum intuito de explicar ou interferir sobre questões por eles levantadas (VERGARA, 2000); entretanto, espera-se, seja uma contribuição para ampliar futuros estudos ou debates sobre essas vivências.

Essa pesquisa foi feita em uma organização pública federal, com sede em Brasília - DF, representada em 10 capitais brasileiras e escritório em alguns municípios. Trata-se de uma instituição tradicional há algumas décadas, constantemente modernizada e líder em solução de tecnologia da informação e comunicações, e que tem uma imagem extremamente respeitada diante da sociedade. Sua força de trabalho é constituída de:

a) Funcionários públicos do quadro de pessoal de níveis médio (técnico) e superior (analista), admitidos por concurso público, com diversas e/ou específicas formações acadêmicas, pertencentes às áreas de apoio ou finalística da organização;

b) Funcionários públicos não pertencentes ao seu quadro de pessoal, que vem de outros órgãos da administração pública ou de empresas contratadas e que ocupa cargos de apoio ou de infra-estrutura, de chefia ou de assessoramento.

Os funcionários públicos categorizados na alínea "a" ascendem aos níveis mais elevados, por mérito ou por antiguidade, por reclassificação ou por avaliação periódica de desempenho. Os de nível superior possuem maior independência para atuarem interna e externamente à organização e tomam as decisões mais importantes; os de nível médio, são admitidos num determinado cargo e nele permanecem até o fim da carreira ou da relação de emprego, exceto se participarem de um novo concurso. Em ambos os níveis podem ter alguma variação salarial positiva temporária ou permanente, caso sejam removidos ou transferidos provisória ou definitivamente para outra unidade da organização. São regidos pela CLT - Consolidação das Leis do Trabalho.

Participaram desta pesquisa 10 (dez) funcionários públicos, sendo 5 (cinco) analistas e 5 (cinco) técnicos do quadro de pessoal concursado da organização, no período de $1^{\circ}$ de abril a 26 maio de 2009 . Destes, 5 são do sexo masculino e 5 do feminino. A faixa etária varia de 30 a 65 anos. Todos possuem mais de 5 anos de trabalho na organização. O quadro a seguir resume bem a demografia deste grupo: 
Perfil dos entrevistados - Quadro Sintético

\begin{tabular}{|c|l|l|c|c|c|}
\hline Entrevista & \multicolumn{1}{|c|}{ Cargo } & \multicolumn{1}{|c|}{ Formação } & Sexo & $\begin{array}{c}\text { Faixa } \\
\text { etária }\end{array}$ & $\begin{array}{c}\text { Tempo na } \\
\text { organização (anos) }\end{array}$ \\
\hline 1 & Analista & $\begin{array}{l}\text { Superior e } \\
\text { Especialização }\end{array}$ & M & $30-35$ & $7-12$ \\
\hline 2 & Técnico & Superior & F & $45-50$ & $30-35$ \\
\hline 3 & Analista & Superior & F & $35-40$ & $25-30$ \\
\hline 4 & Analista & Superior & M & $60-65$ & $34-39$ \\
\hline 5 & Técnico & Superior & M & $40-45$ & $25-30$ \\
\hline 6 & Técnico & Superior & M & $45-50$ & $31-36$ \\
\hline 7 & Técnico & Ensino Médio & M & $50-55$ & $32-37$ \\
\hline 8 & Analista & Superior & F & $40-45$ & $26-31$ \\
\hline 9 & Técnico & Ensino Médio & F & $35-40$ & $27-32$ \\
\hline 10 & Analista & Superior & F & $40-45$ & $15-20$ \\
\hline
\end{tabular}

\subsection{Instrumento da coleta dos dados}

Foi utilizada a técnica de entrevista individual com essas 10 (dez) pessoas. Técnica de entrevista de natureza pessoal, reservada, restrita, baseada em autores como Mendes (2007) e Siqueira (2006), em um roteiro semi-estruturado, elaborado a partir da fundamentação teórica, vislumbrando entender ou elucidar as diversas percepções dos entrevistados sobre os efeitos da organização do trabalho em vivências de prazer e de sofrimento.

Esta organização pública federal possui algum tipo de instância à assistência social, similar a de um setor de psicologia - o Serviço Social - que possibilita recorrer para contrabalançar, dentre outros, os efeitos de vivências de prazer e de sofrimento. Os relatos apurados nas entrevistas apontam situações atuais vivenciadas nesta organização.

\subsection{Procedimentos da coleta de dados}

Os dados, registrados pessoalmente pelo pesquisador, foram coletados do roteiro respondido. A pesquisa foi realizada com o prévio consentimento dos participantes. A forma, o meio e o horário das entrevistas foram definidos de acordo com a conveniência de cada entrevistado e do entrevistador. Foi previamente esclarecido para cada um dos participantes que a entrevista tem por finalidade coletar dados para uma pesquisa acadêmica, sendo garantido sigilo total sobre todo o conteúdo das informações 
respondidas, além da omissão do nome e da unidade de lotação das pessoas. Também, como compromisso firmado, ficou estabelecido que será divulgado aos entrevistados, em local a ser definido, o resultado deste trabalho.

A análise dos resultados foi feita por meio da análise de conteúdo, com a definição de categorias de análise, a fim de facilitar a ligação ou pertinência com o referencial teórico, utilizando Roberto Jarry Richardson (2008). 


\section{Análise e discussão dos resultados}

\subsection{Contexto de trabalho: o dia-a-dia do trabalhador}

O dia-a-dia é desgastante em relação ao trabalho. Uma das principais dificuldades é o atendimento no nível de satisfação do cliente. Uma outra dificuldade enfrentada é a complexidade das atividades e a disponibilidade das informações em tempo hábil. Existem as atividades rotineiras que lidam com preocupação de prazos para atualização dos dados e envio das informações, que requerem agilidade nos serviços, a exemplo de múltiplas tarefas executadas simultaneamente e da exigência de atenção concentrada; e tem as atividades não-rotineiras, que são complexas, que devem ser elaboradas em pouco tempo, também às vezes ocorrendo a indisponibilidade dos dados e/ou dos sistemas de informação. No dia-a-dia há dificuldades com a chefia que às vezes centraliza as informações e que, na sua respectiva ausência, torna-se complicado tomar decisões ou iniciativas porque normalmente as demandas exigem respostas rápidas.

Alguns incômodos existem na convivência com os colegas, como o barulho, por exemplo, e que provocam um certo desvio da atenção na distribuição e gerenciamento das tarefas. No final do mês, quando tem aqueles períodos de picos por conta dos relatórios de fechamento, as tarefas são cumpridas num curto prazo e agravadas ainda mais com a insuficiência de funcionários para a quantidade de trabalho. Existem normas na execução das tarefas e controles manuais através de planilhas, que em alguns casos dificultam o processo da organização e ocupam grande parte do tempo que podia ser utilizado para elaborar com antecedência informações úteis.

Existem cobranças por resultados mesmo diante de momentos de escassez de recursos humanos. A ausência de expectativa de crescimento na organização se dá em determinados aspectos como pela descontinuidade do programa de reclassificação desde o início de 2007, era bienal e até hoje não aconteceu mais. Percebe-se que a maioria desses trabalhadores tem um ritmo de trabalho acelerado, estressante, excessivo ou extremamente excessivo em acúmulos de papéis e atividades de vários processos. Há muita pressão, pois quase tudo envolve prazos a serem cumpridos. Os projetos são numerosos e às vezes com prazos muito curtos e com pressão do cliente; mas, apesar disso, concordam, o ambiente de trabalho é muito bom!

- Cobrança por resultados 
"A cobrança por resultados é atender ao cliente com relação aos pedidos e seguindo o processo..." da organização (metodologia). "O cliente se diz insatisfeito com o atendimento" da organização "contudo, ele não vê que ela passa por momentos de escassez de recursos humanos." (Entrevista $\left.\mathrm{n}^{\circ} 1\right)$.

"A cobrança é normal para o tipo de tarefa. Mas como sou muito dinâmica e me antecipo, não deixo espaço para cobranças." (Entrevista $\left.\mathrm{n}^{\circ} 2\right)$.

"O Resultado cobrado são informações ágeis e corretas superando as dificuldades. As tarefas são cobradas na maioria das vezes para logo, são cumpridas com dificuldades por conta do curto prazo e da falta de funcionário para a quantidade de trabalho. O problema maior é quando temos indisponibilidade dos dados e dos sistemas de informação." (Entrevista $\left.n^{\circ} 10\right)$.

"A cobrança por resultados é a própria execução das tarefas, não havendo indicativos específicos que determinem o resultado, a não ser o cumprimento do processo de faturamento. ” (Entrevista $\mathrm{n}^{\circ} 5$ ).

"Quando há algum atraso de algum dos nossos colegas de trabalho, ai sim, todos são cobrados e temos que encontrar meios de solucionar o problema. " (entrevista $\left.\mathrm{n}^{\circ} 6\right)$.

“... dificil mesmo é quem cobra ter boas maneiras, elou até mesmo métodos adequados para executar tais atividades, com nível de liderança e bom desempenho." (Entrevista $\mathrm{n}^{\circ} 7$ ).

- Ritmo de trabalho

"É um pouco excessivo o ritmo de trabalho, pois acumulo papéis e atividades...” de vários processos “... salvo estas atividades acumulativas, acho que o ambiente de trabalho é muito bom." (Entrevista $\left.\mathrm{n}^{\circ} 1\right)$.

"O volume de trabalho é extremamente excessivo, o ritmo é vertiginoso, talvez 4 ou 5 pessoas o realizasse com mais tranquilidade. Mas como faço o que gosto e sou uma pessoa extremamente dinâmica, tiro de letra. Mas, se eu recebesse um incentivo monetário, com certeza meu prazer seria maior. Há muita pressão, pois tudo envolve prazos a serem 
cumpridos. " (Entrevista $\left.\mathrm{n}^{\circ} 2\right)$.

"Excessivo em alguns momentos de periodos de picos e no final do mês por conta dos relatórios de fechamento. " (Entrevista $\left.\mathrm{n}^{\circ} 10\right)$.

"O ritmo, nos últimos dez dias do mês, é excessivo, por falta de maior organização das tarefas quanto à sua distribuição e competência." (Entrevista $\mathrm{n}^{\circ} 5$ ).

- Execução das tarefas

"Os projetos são numerosos, às vezes com prazos muito curtos e com pressão do cliente. A tarefa de liderança às vezes não é fácil e exige muita paciência em lidar com a área de negócio que recebe os pedidos do cliente e nos repassam." (Entrevista $\left.\mathrm{n}^{\circ} 1\right)$.

"Para as atividades rotineiras: existe preocupação com prazos para atualizações dos dados e envio das informações, agilidade nos serviços, múltiplas tarefas simultaneamente, atenção concentrada, qualidade nas informações e limitações dos recursos. Para as atividades não rotineiras: há preocupação com os prazos, complexidade das informações para elaboração em pouco tempo e indisponibilidade dos dados ou dos sistemas de informação." (Entrevista $\left.\mathrm{n}^{\circ} 10\right)$.

"Nos últimos dias do mês sim, as tarefas são cumpridas com pressão de prazo. Atividades de controladoria, mais especificamente quanto ao faturamento mensal dos serviços prestados ao cliente. Como estamos nos adequando ao novo contrato, ainda não conseguimos cumprir os prazos e isto gera pressão." (Entrevista $\left.{ }^{\circ} 5\right)$.

- $\quad$ Rigidez ou normas para execução das tarefas

"Não há rigidez no meu setor com relação às normas de execução, apenas seguimos o processo..." da organização "o qual está embasado no CMMI nível 2. "(Entrevista $\left.\mathrm{n}^{\circ} 1\right)$.

"Existem normas e em alguns casos dificultam o processo. Existem controles manuais através de planilhas, ocupam grande parte do tempo que podia ser utilizado para elaborar com antecedência informações úteis. (Entrevista $\left.{ }^{\circ} 10\right)$. 
- Dificuldades com a chefia / equipe de trabalho

"Não tenho queixas das chefias e da equipe de trabalho, visto que me dou bem com todos eles" (Entrevista $\mathrm{n}^{\circ} 1$ ).

"A dificuldade maior é com relação às informações que ficam centralizadas e, em alguns casos, principalmente na ausência da chefia é necessário tomar algumas decisões/iniciativas ou responder questionamentos sobre o trabalho e fica dificil porque as pessoas querem respostas rápidas. Dificuldades com colegas, muito raro acontecer, o caso mais recente foi quando um colega não queria atender o cliente, passar uma informação que era da responsabilidade dele, simplesmente por achar que o cliente estava exigindo muitos detalhes e eu por estar substituindo a chefia, tive que intervir, para que ele passasse a informação sem causar maiores problemas." (Entrevista $\mathrm{n}^{\circ}$ $10)$.

"Para ser chefe é necessário o minimo de conhecimento de liderança, flexibilidade, visão geral da área de atuação, comprometimento com o todo." (Entrevista n ${ }^{\circ}$ 7).

- Distribuição das tarefas / expectativa de crescimento na organização "Participo de todas as decisões, quanto à distribuição de tarefas, $e$ minha opinião sempre é levada em consideração. (Entrevista $\mathrm{n}^{\circ} 2$ ).

“... espero que o processo de reclassificação saia em breve, pois este processo era bienal e ainda não aconteceu desde o início de 2007." (Entrevista $\left.\mathrm{n}^{\circ} 1\right)$.

“...são poucas as expectativas de crescimento, espero que o novo plano de cargos e salários traga promoções significativas. Não participo da distribuição das tarefas, a chefia as distribui de acordo com o perfil e disponibilidade." (Entrevista n $\left.{ }^{\circ} 10\right)$.

"Participo de parte da distribuição das tarefas. A gerência conversa com a equipe quanto a execução das atividades, só que devido a adequação às exigências do novo contrato, esta distribuição, por vezes, é tumultuada." (Entrevista n ${ }^{\circ}$ 5). 
"Não participo das decisões, a distribuição é realizada como a chefia quer, porque não há abertura para tal." (Entrevista $\left.\mathrm{n}^{\circ} 8\right)$.

\subsection{Exigências decorrentes do contexto de trabalho}

Geralmente, as exigências decorrem quando alguém deve executar um trabalho e este não foi concretizado ou realizado a contento. Mas, os trabalhadores estão preocupados em atender o cliente com o desempenho exigido pela organização e percebe-se que a maioria deles está sempre voltada para atender bem o cliente, com a maior presteza e completude possível, por serem muito responsáveis nas suas atribuições, buscando contornar o que for necessário e estiver ao seu alcance para atender à satisfação do cliente. E eles têm-se deparado com questões de ordem de controle das emoções, de ordens contraditórias, de agressividade dos outros, submissão a constrangimentos, de solução de problemas, pois grande parte das atividades em si por serem complexas, já exigem uma resolução de problema constante.

No curto espaço de tempo, onde as informações são solicitadas e o fato de terem que acelerar para atender as demandas, verifica-se um grande desconforto desses trabalhadores, que por vezes se irritam com repetição de ordens que geram atividades diversas para um mesmo objetivo, por exemplo.

O poder de quem o detém e o medo de perdê-lo gera contra-ordem, confirma e reflete a concorrência pela supremacia na organização. Pessoas ávidas por poder dão contra-ordens, mesmo quem não o detenha mas o quer, e se impõem de todas as formas, até mesmo para serem notadas saltitam visando serem vistas para que percebam que existem. Por outro lado, essas contra-ordens podem ser evitadas ou minimizadas por meio de reuniões de trabalho regulares ou frequentes. Atividades físicas diversas ou a prática de esportes pode ajudar a evitar o constrangimento melhorando a qualidade vida, a saúde, pois pela participação há a integração das pessoas surgindo a amizade e mais afinidades entre elas.

Embora observando critérios ou normas, os trabalhadores evitam sair no horário de expediente de trabalho, principalmente quando podem prejudicar as atividades mais complexas, mas às vezes o contexto de trabalho ainda lhes impõe dificuldades quando precisam ausentar-se do trabalho por razões pessoais, mesmo tendo direito a dias de abono ou de férias, alegando que sua ausência ocorre no momento em que a organização mais precisa dele. Pode-se concluir que isso é um problema de algum 
gerenciamento específico ou localizado e não de toda a organização. Com isso, presume-se, que neste caso está faltando algumas ponderações que o gerente deve ter como o mínimo de conhecimento de liderança, flexibilidade, visão geral da área de atuação, comprometimento com o todo.

- Controle das emoções

"Em função do cliente, já tive um desgaste com uma pessoa da área de negócio. Esta pessoa já chegou a me ligar na hora do almoço cobrando posicionamento de pedidos." (Entrevista $\left.\mathrm{n}^{\circ} 1\right)$.

"Não especificamente ordem contraditória, mas uma repetição de ordens que geram atividades diversas para um mesmo objetivo." (Entrevista $\left.n^{\circ} 5\right)$.

“... chefe e colegas mau-humorados, descarregando seus problemas sobre sua boa vontade, e ambos estragando o seu dia que poderia ser proveitoso. Lidar com pessoas por si só já é complicado, agora lidar com pessoas que se encontrem nas condições citadas acima, é barra Leão, Elefante ou outros animais de força. Ser chefe é liderar e não mandar, é vislumbrar vitórias juntos, é desinflar o ego, como por exemplo: eu fiz, eu faço, eu mando, eu mandei, etc, etc e etc; deve ser trocado por nós fazemos, nós fizemos, nós faremos, nós desenvolvemos e etc." (Entrevista $\left.n^{\circ} 7\right)$.

"Informações solicitadas em curto espaço de tempo e ter que acelerar para atender a demanda, há uma grande necessidade de controle das emoções. Necessidade de me ausentar por razões pessoais, mesmo tendo direito a dias de abono/férias e negociando com antecedência com a chefia, esta põe dificuldades alegando que no momento que mais precisa eu estou fora. Quando a chefia diz que mais precisa é só por questões pessoais e particulares, pois sempre procuro sair sem prejudicar as atividades mais complexas." (Entrevista $\left.\mathrm{n}^{\circ} 10\right)$.

"Porque somos seres humanos, sempre há controle das emoções na falta de alguém que deveria realizar um trabalho e não foi concretizado." (Entrevista $\left.n^{\circ} 6\right)$.

- Ordens contraditórias / agressividade dos outros / constrangimentos 
"O cliente liga impacientemente cobrando as áreas de negócio e o desenvolvimento de sistemas para que os sistemas de informação funcionem corretamente e, às vezes, em tom agressivo. "(Entrevista $\left.\mathrm{n}^{\circ} 1\right)$. "Em todo lugar, no cliente e na organização, há pessoas agressivas, ávidas por poder e, mesmo que não o detenha, tentam se impor de todas as formas, inclusive dando contra-ordens. Mas me considero uma pessoa sensata e sei que, mesmo ficando chateada, não vale a pena me desgastar pois, afinal, tudo que essa pessoa está querendo é ser notada. Seu lema é: "Por favor, percebam que eu existo!". Essa tática não costuma funcionar muito comigo, quanto mais elas me pedem nesses termos, mais eu as ignoro!" (Entrevista $\left.\mathrm{n}^{\circ} 2\right)$.

$\mathrm{Na}$ minha área "ainda não tivemos ordens contraditórias, por que temos reuniões justamente para não acontecer este tipo de problema. Já fui constrangido, já fui taxado de maluco, mas nada que me fizesse recuar, pois tenho absoluta certeza que, em primeiro lugar, devemos ter $e$ priorizar a nossa saúde. Em qualquer atividade da nossa vida temos que ter saúde, o resto a gente vai conquistando." (Entrevista $\left.\mathrm{n}^{\circ} 6\right)$.

"Tive constrangimento quando o chefe gritou na presença de amigos e visitantes." (Entrevista $\left.n^{\circ} 7\right)$.

- Resolver Problemas

"Frequentemente sou cobrado para publicar arquivos urgentemente e realizar alterações urgentes as quais o próprio cliente não tem controle." (Entrevista $\left.{ }^{\circ} 1\right)$.

"As atividades em si já exigem uma resolução de problema constante." (Entrevista $\left.n^{\circ} 5\right)$.

\subsection{Problemas (físicos, psicológicos e sociais) nos últimos 6 meses causados, essencialmente, pelo trabalho}

O trabalho tem provocado aos trabalhadores da organização diversas ou variadas patologias. Dores de cabeça e alterações do apetite e do sono, devido às frequentes mudanças organizacionais e à sobrecarga de trabalho. Como também tem surgido alguns casos de mau-humor ou irritabilidade, conflitos nas relações familiares, 
impaciência com as pessoas em geral, vontade de ficar sozinho e dúvida sobre a capacidade de fazer as tarefas. E agravado situações como problema de coluna, cóccix e retenção de líquido por ficar em assento por muito tempo e sem descanso. E labirintite, além de tendinite, ansiedade, alteração da pressão arterial e estresse; problemas de visão, como vista irritada por ficar muitas horas em frente ao computador.

“Dores de cabeça, sinto às vezes." (Entrevista $\left.\mathrm{n}^{\circ} 1\right)$.

"Agravamento do problema de coluna, cóccix e visão, por ficar sentada por mais de 8 horas em frente ao computador, sem descanso; problema de alergia respiratória por produtos: perfumes usados pelos colegas; $e$ labirintite e enxaqueca, causados pelo estresse." (Entrevista $\left.\mathrm{n}^{\circ} 2\right)$.

"Tendinite, ansiedade e estresse. Dores no corpo / dores de cabeça, quase sempre eu sinto." (Entrevista $\left.\mathrm{n}^{\circ} 10\right)$.

"Tive algum problema nos últimos 6 meses de alteração na pressão arterial, de irritabilidade com os colegas. Quase sempre tenho vontade de ficar sozinho e tenho dúvida sobre a capacidade de fazer as tarefas." (Entrevista $\left.n^{\circ} 5\right)$.

"Quase sempre tenho alterações do apetite e do sono. LER (Lesão por Esforços Repetitivos) nas mãos. Ficar sentada o dia todo me causa retenção de liquido, usar o computador o dia todo fico com a vista irritada. Sinto angústia, tristeza, ansiedade de não ter com quem conversar, ser vigiada o dia todo, ser avaliada pela chefia de forma não ética, sinto raiva. (Entrevista $\left.\mathrm{n}^{\circ} 8\right)$.

“Algumas vezes tive conflitos nas relações familiares." (Entrevista $\left.{ }^{\circ} 1\right)$.

"Estresse no trabalho." (Entrevista $\left.{ }^{\circ} 4\right)$.

\subsection{Percepções nos últimos 6 meses sobre os efeitos em vivências de prazer e de sofrimento}

Às vezes, fica difícil visualizar ou analisar relatos de vivências positivas em certos aspectos, mas de vivências negativas sobressaem várias e de diversas formas pelas mudanças havidas na organização com bastante frequência, indefinições por parte de dirigentes que não têm poder de decisão, intranquilidades dos trabalhadores desprestigiados ou desvalorizados e valorizados por outros métodos, excesso de trabalho, de cobrança, ritmo acelerado, problemas no reconhecimento do esforço e do 
desempenho com incentivos ao aumento da produtividade, cliente pouco ou nada satisfeito, cumprimento de horário rígido e desconfiança na chefia do setor pelo trabalhador por não ter espaço para o diálogo ou ser ouvido e por não poder participar de outras atividades inerentes na área. Algumas chefias não têm conhecimento suficiente dos problemas da organização e dos seus subordinados. Por vezes, a organização promove workshops em demasia e sem perspectivas. Falta um programa de auto-estima ou de lazer, visando mais à integração e sociabilização dos trabalhadores, para que todos possam ter uma qualidade de vida melhor. A implementação de um programa de qualidade de vida não se restringe somente às atividades de saúde ocupacional do trabalhador dentro da organização; mas, também fora da organização e regularmente. Por exemplo, no clube dos trabalhadores da organização, num parque, no jardim botânico ou noutros lugares, dando oportunidade àqueles que se dispõem a fazêlo. E como incentivo aos participantes, por exemplo, estes poderiam ter a liberdade de chegar um pouco mais tarde no trabalho ou um horário flexível não prejudicando sua jornada de trabalho nem suas atividades, com isso, haveria mais alegria, mais produção e menos doenças, pela certeza de uma melhoria na qualidade de vida para todos.

As vivências positivas são discretamente relatadas por esses trabalhadores que têm um ambiente de alegria porque há a cordialidade, a colaboração da equipe com o compartilhamento dos serviços, busca constante por resultados, novas responsabilidades, disciplina e perspectivas de dias melhores. Quase sempre têm liberdade com a chefia para negociar o que precisam ou necessitam, pois conversam sobre as atividades, e as decisões são na maioria das vezes acolhidas pela gerência. Têm liberdade de falar sobre o seu trabalho com os colegas, a conversa flui normalmente. E a satisfação, em termos gerais ao menos, não há insatisfação quanto às suas atividades. É pouca a motivação, pois não são percebidas ações próprias que levem à motivação, ela é buscada no próprio indivíduo. Nem sempre há algo direto para ser percebido o reconhecimento do esforço, do desempenho, mas não há um desprezo também. Há a expectativa de terem novas oportunidades e de aprenderem coisas novas com os colegas. E têm a sensação de segurança e a oportunidade de crescerem como pessoa.

- Motivação, satisfação e reconhecimento

"Há pouca motivação. Acho que a empresa deveria motivar mais seus funcionários no reconhecimento do esforço e do desempenho. Ela deveria reconhecer com melhores salários e incentivos ao aumento da 
produtividade." (Entrevista $\left.{ }^{\circ} 1\right)$.

"Não ter reconhecimento financeiro é a maior vivência negativa e essa engloba tudo." (Entrevista $\left.\mathrm{n}^{\circ} 2\right)$.

"Há pouca motivação. Não percebo ações próprias que levem a motivação, ela é buscada no próprio individuo. Não percebo algo direto para o reconhecimento, mas não há um desprezo. " Entrevista ${ }^{\circ}$ 5).

- Cooperação entre os colegas e liberdade com a chefia para negociar o que precisa, ambiente de trabalho, outros

"Quase sempre tem-se liberdade com a chefia para negociar o que precisa. Sempre conversamos sobre as atividades, e as decisões são acolhidas pela gerência." (Entrevista $\left.\mathrm{n}^{\circ} 5\right)$.

"Colaboração da equipe, compartilhamento dos serviços, novas responsabilidades, troca de ideias com os meus colegas de trabalho, um ambiente de alegria, cordialidade por todos, apoio em todos os aspectos relacionados ao trabalho, disciplina e perspectivas de dias melhores, um grupo de amigos e solidários, busca constante pelo resultados, integração com todos no trabalho. Workshops em demasia e sem perspectivas, pessoas desmotivadas sem nenhum interesse, falta um programa de auto-estima, falta um programa de integração $e$ sociabilização, de lazer, para que todos possam ter uma qualidade de vida melhor..." (Entrevista $\left.{ }^{\circ} 6\right)$.

"Ter disposição para trabalhar, gostar de trabalhar, ter o meu salário no final do mês, ter oportunidade de crescer em conhecimentos, ter colegas para conversar na empresa, fazer novas amizades na empresa, ocupar o tempo com coisas úteis, expectativa que vou ter novas oportunidades, aprender coisas novas com os colegas, ter a sensação de segurança, oportunidade de crescer como pessoa. Não ter expectativas de crescimento na empresa, aguentar a infantilidade das chefias do setor, ter que suportar as discriminações por parte dos colegas e da chefia do setor, não confiar na chefia do setor, ser discriminada por estar aposentada, estar subaproveitada no setor onde estou no momento, ter que cumprir horário rígido, não apresentar resultados satisfatórios 
de acordo com o meu conhecimento, não ter espaço para dialogar e ser ouvida, ter que aguentar colega preguiçosa, não poder participar de outras atividades." (Entrevista $\left.\mathrm{n}^{\circ} 8\right)$.

- Competitividade, discriminação, injustiça, indignação, desqualificação "Excesso de trabalho, excesso de cobrança, cliente nada satisfeito, cliente sem saber o que quer, mudanças na empresa a toda hora, chefias sem poder de decisão, funcionários valorizados por outros métodos, desvalorizações de funcionários, funcionários desprestigiados, indefinição por parte da diretoria da empresa." (Entrevista $\left.\mathrm{n}^{\circ} 4\right)$.

\section{Quadro resumo dos efeitos em vivências}

O quadro resumo a seguir apresenta uma síntese de informações sobre os efeitos da organização do trabalho em vivências de prazer e de sofrimento de trabalhadores em uma organização pública federal.

\begin{tabular}{|l|l|}
\hline $\begin{array}{l}\text { Contexto de } \\
\text { trabalho }\end{array}$ & $\begin{array}{l}\text { Percepções: } \\
\text { O dia-a-dia é desgastante. O ritmo de trabalho é acelerado. Existem } \\
\text { pressões para alcançar resultados. Os efeitos advêm da escassez de } \\
\text { recursos humanos, da indisponibilidade dos dados e/ou dos sistemas de } \\
\text { informação e das dificuldades de atendimento no nível de satisfação do } \\
\text { cliente. } \\
\text { Análise: } \\
\text { O contexto de trabalho está voltado para indicadores de saúde com as } \\
\text { vivências de prazer, que surgem dos elementos flexíveis da organização, } \\
\text { do agradável ambiente de trabalho e da liberdade de expressão, na maioria } \\
\text { das vezes. Ao contrário, existem indicadores de adoecimento, que } \\
\text { aparecem, de certa forma, pelo despreparo do corpo gerencial da } \\
\text { organização na gestão de pessoas, pela rigidez nos prazos fixados do } \\
\text { atendimento das demandas e pela dificuldade dos órgãos para apontarem } \\
\text { com mais amplitude ou precisão o caminho das regras de negócio no } \\
\text { atendimento de demandas do cliente. }\end{array}$ \\
\hline $\begin{array}{l}\text { Exigências } \\
\text { decorrentes }\end{array}$ & $\begin{array}{l}\text { Percepções: } \\
\text { O trabalho deve ser executado ou concretizado a contento. Os }\end{array}$ \\
\hline
\end{tabular}




\begin{tabular}{|c|c|}
\hline & $\begin{array}{l}\text { trabalhadores estão preocupados em atender o cliente com o desempenho } \\
\text { exigido pela organização. } \\
\text { Análise: } \\
\text { As exigências sugerem, nesse cenário, posicionamentos da organização } \\
\text { para continuar preservando tempestivamente o cumprimento das leis, e } \\
\text { com presteza e economicidade o atendimento ao cliente, o cliente- } \\
\text { cidadão, a sociedade em geral. }\end{array}$ \\
\hline $\begin{array}{l}\text { mas } \\
\text { ógicos }\end{array}$ & $\begin{array}{l}\text { Percepções: } \\
\text { Os efeitos físicos, psicológicos e sociais provocados pelo trabalho nesta } \\
\text { organização nos últimos } 6 \text { meses têm sido diversos e, em geral, são } \\
\text { devidos às frequentes mudanças organizacionais, ao insignificativo poder } \\
\text { aquisitivo da maioria dos trabalhadores e à sobrecarga de trabalho. Para se } \\
\text { verem livres desses problemas, atividades alternativas são utilizadas pelos } \\
\text { trabalhadores, como subterfúgio, participando de novos concursos } \\
\text { públicos com o objetivo de alcançar outra situação ou mudança de } \\
\text { ambiente de trabalho, também vislumbrando maior poder aquisitivo, } \\
\text { terem mais liberdade e se verem livres das amarras que os colocam nesse } \\
\text { cenário indesejável. } \\
\text { Análise: } \\
\text { Em não havendo mudanças expressivas em prol das vivências positivas, a } \\
\text { organização vai perdendo seu recurso imprescindível, senão o mais } \\
\text { importante, que é o seu capital humano e, consequentemente, vai-se } \\
\text { fragilizando sua estrutura ou sua cultura organizacional. }\end{array}$ \\
\hline $\begin{array}{l}\text { cias } \\
\text { timos } \\
\text { es }\end{array}$ & $\begin{array}{l}\text { Percepç̃es: } \\
\text { Nos últimos } 6 \text { meses, percebe-se que houve mudanças na organização } \\
\text { com bastante frequência, verifica-se que há dirigentes que não têm poder } \\
\text { de decisão, tem-se a intranquilidade dos trabalhadores desprestigiados ou } \\
\text { desvalorizados e valorizados por outros métodos, existem o excesso de } \\
\text { trabalho, de cobrança, ritmo acelerado e o cliente pouco ou nada } \\
\text { satisfeito. As vivências positivas são discretamente relatadas por esses } \\
\text { trabalhadores que têm um ambiente de alegria porque há a cordialidade, a } \\
\text { colaboração da equipe com o compartilhamento dos serviços, busca } \\
\text { constante por resultados, novas responsabilidades, disciplina e }\end{array}$ \\
\hline
\end{tabular}




perspectivas de dias melhores.
Análise:
A pesquisa aponta à organização a necessidade de investimentos em
capacitação, principalmente em políticas e práticas de gestão de pessoas,
de ajustes ou adequações nos planos de cargos e salários vigentes com
definições de propósitos transparentes, amplos e objetivos, de novas
diretrizes com a definição participativa de planos e metas e com o
aprimoramento do processo de avaliação de desempenho, visando
reorientar determinados segmentos de direção e subordinação de modo a
otimizar esforços ou desempenho. E para ajudar a reduzir a pessoalidade e
o retrabalho, deve-se utilizar sempre mais de ferramentas integradas de
gestão e de técnicas de gestão mais flexíveis e aprimoradas.




\section{Considerações finais}

Esta pesquisa teve como objetivo investigar os efeitos da organização do trabalho em vivências de prazer e de sofrimento de trabalhadores que atuam em uma organização pública federal, num ambiente de trabalho moderno, virtual, na maioria das vezes denominado de estação de trabalho. Destacou as vivências positivas e vivências negativas e investigou problemas físicos, psicológicos e sociais que estiveram ou estão presentes na vida desses trabalhadores causados, essencialmente, pelo seu trabalho, trazendo uma ideia ou juízo de melhor entendimento sobre se:

- O efeito do gerencialismo dentro de uma organização pública federal causa sofrimento ao indivíduo;

- A nova gestão pública, com seus indicadores de desempenho, causa sofrimento ou fatores de risco para a saúde e para a qualidade de vida no trabalho.

Com base nos resultados analisados, verificou-se que o prazer nas vivências positivas advém da realização profisssional, do agradável ambiente de trabalho que possui esta organização e da liberdade de expressão, na maioria das vezes. $O$ sofrimento, que são as vivências negativas, vem do estresse devido ao excesso de trabalho, pressões de prazos de realização das tarefas, do desgaste produzido ao longo de muitos anos de trabalho, do ambiente virtual de atuação desses trabalhadores. Podese afirmar que este contexto de trabalho está voltado para indicadores de saúde, que representam vivências de prazer, e para indicadores de adoecimento, que representam vivências de sofrimento. As vivências de prazer surgem dos elementos flexíveis da organização, como autonomia do horário de trabalho com o registro de ponto flexível ou por exceção; flexibilidade para organizar as tarefas; liberdade para manifestar ou expressar as características individuais o que ocorre, principalmente, nas reuniões periódicas das equipes, na cooperação entre os pares ou colegas de trabalho. As vivências de sofrimento aparecem principalmente pela falta de expectativa ou clareza de crescimento na carreira por meio da reclassificação, por exemplo, que antes era dado como certo esse prêmio a ser concorrido e democraticamente adquirido. Também, estas vivências aparecem, em alguns casos, pelo despreparo do corpo gerencial no que se refere à gestão de pessoas, que se traduz num desequilíbrio de forças: às vezes, tem-se um excelente técnico, mas não se tem um competente gerente, e o inverso ocorre também. O sofrimento está presente pela rigidez nos prazos fixados do atendimento das 
demandas, que, quase sempre, são curtos demais. O demandante, muitas vezes é ou deve ser irredutível, pois na implementação de novas funcionalidades de processos ou nas adaptações ou ajustes das já existentes, e em alguns casos para atenderem a determinação da lei, são exigidos prazos muito curtos para serem cumpridos. Alguns órgãos, mesmo externos a esta organização, muitas vezes não estão preparados para apontarem o caminho das regras de negócio com mais amplitude e precisão; ou, acham que a organização está sempre e só a serviço deles, não vêem devidamente o outro lado, ou não se colocam diante da realidade com o tratamento adequado, respeitoso, que existem limitações e que a organização também está voltada para atender com zelo e economicidade o cidadão-cliente ou a sociedade em geral.

Todo esse cenário faz com que muitos servidores tendem a se investir em atividades alternativas, no preparo para novos concursos públicos, visando melhorias como estratégia de enfrentamento e deixando a organização num curto espaço de tempo. Quando passam, são aprovados, vão trabalhar em outros órgãos sempre ganhando mais. Entretanto, tem-se verificado, segundo relato que, muitas das vezes quando chegam no outro órgão público, acabam sentindo-se mal ambientado, porque lá não existe esse clima daqui, esse ambiente agradável de trabalho, e de certa forma ficam arrependidos, mas já é tarde! E, nesse ínterim, quem mais perde é esta organização pública federal.

Também, constatamos que o modelo gerencial implantado na administração pública contribuiu para o agravamento do sofrimento no trabalho, uma vez que restringiu direitos dos trabalhadores impondo novas ordenações do setor empresarial, que visa o lucro tão-somente; e o setor público, não; este não visa o lucro e sim atua com economicidade e tempestividade para atender a sociedade. Este modelo acarretou desgaste da imagem dos servidores públicos, causando como consequência o agravamento do reconhecimento no desempenho da carreira, uma vez que o serviço público está diretamente relacionado com questões normativo-legais, com o social e o lado político e não apenas com o lado empresarial, o da iniciativa privada. E a administração pública tem uma lógica própria de funcionamento, requerendo, para isso, o desenvolvimento de técnicas de gestão adequadas, além de uma formação específica para os gestores públicos, como também tende ao rompimento com os modelos administrativos e fórmulas prontas, porque estes não são capazes de refletir ou de atender a complexidade dos processos políticos e sociais.

Para melhorar esse quadro, aponta a pesquisa, serão necessários mais 
investimentos específicos em capacitação; novas diretrizes com a definição participativa de planos e metas, visando reorientar todos os segmentos de direção e subordinação de modo a otimizar esforços; reduzir a pessoalidade e o retrabalho utilizando para isso, inclusive, novas ferramentas integradas de gestão; além de novas políticas e práticas de gestão de pessoas, com a otimização do processo de avaliação de desempenho na gestão de pessoas; ajustes ou adequações nos planos de cargos e salários vigentes com definições de propósitos transparentes, amplos e objetivos.

Enfim, é possível mudar o cenário vislumbrado, alcançar um nível maior de maturidade produzindo melhor os bens e serviços de que a sociedade e governo tanto precisam, porque o trabalho não deve ser um sofrimento no dia-a-dia; mas sim, deve ser um desafio auspicioso todo dia, alegre, feliz, uma fonte renovável de prazer e de bemestar social individual e coletivo. Somente dessa forma, com essa lógica própria de funcionamento do serviço público e com relevantes investimentos em recursos humanos e tecnologia, uma organização pública federal manterá o equilíbrio com o melhor quadro de pessoal técnico e gerencial preservando sua cultura organizacional e sua perenização diante da sociedade prestando um serviço justificadamente necessário ou indispensável. 


\section{Referências}

BRESSER-PEREIRA, L. C.; SPINK, P. Gestão do setor público: estratégia e estrutura para um novo estado. In: ___ (Org.). Reforma do estado e administração pública gerencial. Rio de Janeiro: FGV, 1998, p.21-38.

DEJOURS, C. A banalização da injustiça social. Rio de Janeiro: FGV, 2007.

DE PAULA, A. P. P. Por uma nova gestão pública: limites e potencialidades da experiência contemporânea. Rio de Janeiro: FGV, 2005.

GAULEJAC, V. Gestão como doença social. Aparecida, SP: Ideias \& letras, 2007.

MENDES, A. M. Psicodinâmica do trabalho. São Paulo, SP: Casa do psicólogo, 2007.

RICHARDSON, R. J. Pesquisa social - Métodos e técnicas. São Paulo: Editora atlas, 2008.

SIQUEIRA, M.V.S. Gestão de pessoas e discurso organizacional. Goiânia, GO: Editora da UCG, 2006.

VERGARA, S. C. Começando a definir a metodologia. In: Projetos e relatórios de pesquisa em administração. São Paulo, SP: Atlas, 2000, cap. 4. 